Maurer School of Law: Indiana University

Digital Repository @ Maurer Law

2011

\title{
Morrison v. National Australia Bank: Defining the Domestic Interest in International Securities Litigation
}

Hannah Buxbaum

Indiana University Maurer School of Law, hbuxbaum@indiana.edu

Follow this and additional works at: https://www.repository.law.indiana.edu/facpub

Part of the Securities Law Commons

\section{Recommended Citation}

Buxbaum, Hannah, "Morrison v. National Australia Bank: Defining the Domestic Interest in International Securities Litigation" (2011). Articles by Maurer Faculty. 814.

https://www.repository.law.indiana.edu/facpub/814

This Article is brought to you for free and open access by the Faculty Scholarship at Digital Repository @ Maurer Law. It has been accepted for inclusion in Articles by Maurer Faculty by an authorized administrator of Digital Repository @ Maurer Law. For more information, please contact rvaughan@indiana.edu. 
become a meaningful way to exert greater influence beyond what they could expect as a result of multilateral negotiation. Americans should be concerned that, following the U.S. lead, other countries will embrace extraterritoriality as a way to impose liability on Americans for conduct occurring in the U.S. and lawful under U.S. law, that is alleged to have an effect abroad.

While these criticisms of the effects approach are significant, Professor Dodge and I share some common ground. Extraterritorial regulation is not always a bad idea. In under-regulated areas, extraterritoriality can sometimes fill a gap. And it may be that extraterritorial regulation can serve as a placeholder before more comprehensive, international agreement can be reached. Certainly, there is no problem with a nation regulating its own citizens and subjects abroad. But Congress should not take the decision to regulate extraterritorially lightly, and, in the face of congressional silence, courts should not simply assume that Congress intended to regulate whenever an effect in the United States exists.

The Morrison case reaffirmed these basic principles. Contrary to Professor Dodge's reading, Morrison correctly interred the effects test and reaffirmed that Congress is presumed to have exercised only its territorial jurisdiction. For those who see the value in primarily resolving global challenges through multilateral agreement, rather than through unilateral domestic action, that is good news indeed.

\section{Morrison v. National australia Bank: Defining the DomestiC INTEREST IN INTERNATIONAL SECURITIES LiTIGATION}

\section{By Hannah L. Buxbaum*}

In Morrison, the U.S. Supreme Court addressed for the first time the extraterritorial reach of Section 10(b) of the Exchange Act. It did so against the backdrop of a jurisprudence developed by the lower federal courts, pursuant to which legislative jurisdiction over crossborder securities claims rested on two alternative bases: conduct occurring within the United States, and effects within the United States of conduct occurring abroad. ${ }^{1}$ Both the District Court for the Southern District of New York and the Second Circuit Court of Appeals had ruled in favor of the defendants, concluding that U.S. law did not apply to the plaintiffs' claims. They did not, however, accept the defendants' invitation to adopt a bright-line rule that conduct could never suffice as a basis for jurisdiction over foreign-cubed claims-that legislative jurisdiction could never be established where the conduct in question had "no effect in the United States or on American investors." 2

The Supreme Court adopted precisely such a bright-line rule-and one that applies not just to foreign-cubed cases, which present particularly serious international comity concerns, but to all types of cross-border securities claims. Rejecting the longstanding conduct and effects tests, the Court adopted in their place a single transaction-based test. Concluding that "the focus of the Exchange Act is not upon the place where the deception originated, but upon purchases and sales of securities in the United States,"3 it held that Section 10(b)

\footnotetext{
- John E. Schiller Chair in Legal Ethics and Executive Associate Dean for Academic Affairs, Indiana University, Maurer School of Law.

${ }^{1}$ This approach is consistent with the jurisdictional analysis used in other substantive areas. See generally Restatement (ThiRd) of the Foreign Relations Law of the United States $\$ \$ 401-403,416$ (1987).

${ }^{2}$ Morrison v. National Australia Bank, Ltd., 547 F.3d 167, 174 (2d Cir. N.Y. 2008).

${ }^{3}$ Morrison v. National Australia Bank, Ltd., 130 S. Ct. 2869, 2884 (2010).
} 
applies to fraud only in connection with "transactions in securities listed on domestic exchanges, and domestic transactions in other securities." 4

The Court presented this test as flowing from the presumption against extraterritorialitybut does it in fact foreclose the extraterritorial application of U.S. securities law? What Section 10(b) prohibits, on the Court's reading, is fraud in connection with U.S. securities transactions-but nothing in the opinion states that the fraud itself must take place within the United States in order to trigger application of Section 10(b). Rather, it implies that wherever that fraud occurs, if it affects a U.S. transaction, it falls within the scope of 10(b). Thus, while the decision rejects the old effects test as such, it does not reject the sufficiency of certain domestic effects-that is, harm suffered in domestic securities transactions-as an acceptable basis for regulation.

But if U.S. securities law does apply to some foreign conduct-that which affects U.S. market transactions-then the presumption against extraterritoriality has been overcome. If the Court had recognized this, and had as a result not applied the presumption, then what? In his own dissenting opinion in the 1993 Hartford Fire antitrust case, Justice Scalia provides the answer. " $[I] f$ the presumption against extraterritoriality has been overcome or is otherwise inapplicable, a second canon of statutory construction [the Charming Betsy canon] becomes relevant: ' $[\mathrm{A}] \mathrm{n}$ act of congress ought never to be construed to violate the law of nations if any other possible construction remains." ${ }^{, 5}$ In other words, we turn to international lawto principles of international comity and the need to avoid unnecessary interference with the interests of other nations.

In my view, a comity approach would permit a more nuanced analysis of the jurisdictional problem that Morrison presented, and would have been better situated within the international law framework than the mode of statutory construction actually adopted by the Court. To focus on the limitations of the Morrison approach, let us walk again through the majority opinion's line of reasoning. Justice Scalia's opinion begins by quoting Aramco on the presumption against extraterritoriality: "legislation of Congress, unless a contrary intent appears, is meant to apply only within the territorial jurisdiction of the United States. "6 This alone is not terribly helpful: it could mean that it was meant to apply to conduct occurring within the United States, or it could mean that it was meant to apply to conduct whose effects occur within the United States, or both. And so it is given content by reference to Congress' legislative interests: "the perception that Congress ordinarily legislates with respect to domestic, not foreign matters." 7 And how are "domestic matters" to be defined in the context of securities regulation? The opinion states that "[n]othing suggests that this national public interest pertains to transactions conducted upon foreign exchanges and markets." ${ }^{, 8}$ in other words, the Court concludes, a focus on Congress' aims in adopting the Exchange Act shows that the intention of Congress was to regulate only domestic securities transactions. "[T]he focus of the Exchange Act is not upon the place where the [fraud] originated, but upon purchases and sales of securities in the United States."9 Thus, the antifraud provision reaches only conduct in connection with a U.S. transaction.

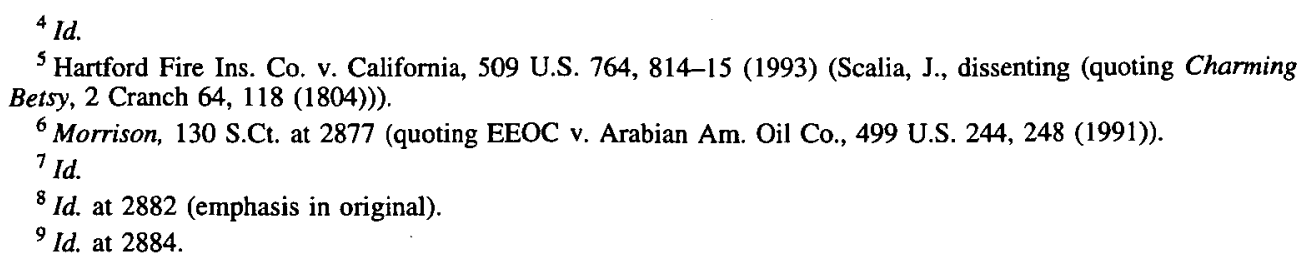


This line of analysis articulates a cramped vision of the "domestic interest" in securities regulation. Surely at this point in the development of the global economy, the U.S. domestic interest in regulation extends beyond specific transactions conducted on our markets or within our borders. First, setting aside exchange-based trading, it will be a messy matter indeed to define the location of a transaction. What about trades executed by American investors through foreign-hosted websites? Or through U.S. affiliates of foreign brokerages? What about, to take a recent case, swaps that are executed by hedge funds in the United States but that reference the price of foreign shares? ${ }^{10}$ It may no longer be feasible to define "domestic transaction" with the clarity the Court seeks. Second, the flow of transactions on global markets means that domestic conditions within the United States can sometimes be affected even if the specific claim in question does not flow from a domestic transaction. Consider, for example, a foreign company with securities listed both in the United States and abroad. That company could choose deliberately to release fraudulent information in the United States, knowing that even after paying resulting damages to its U.S. investors, it would come out ahead because foreign investors would not be able to mount a successful private action. Is there not a U.S. interest in deterring such fraud, thereby reducing ongoing private enforcement costs within the United States? Third, the U.S. regulatory interest encompasses shared concerns with other countries regarding the need for effective global regulation. Consider, for example, the very common situation in which an act of fraud affects both a group of U.S. investors who transacted in the United States and a group of foreign investors who transacted on a foreign exchange. Wouldn't efficiencies be gained in avoiding duplicative litigation in multiple jurisdictions?

It would be one thing to recognize this more expansive set of interests but to say that there are reasons despite them to adopt a territorial, transaction-based test. The way to do that, as I have argued elsewhere, is to refer to principles of international comity, and the need to avoid unnecessary interference with regulatory efforts by other nations-in other words, to focus on the conflict that application of U.S. law would create with other jurisdictions. ${ }^{11}$ But according to the Morrison opinion, "[t]he . . . presumption applies regardless of whether there is a risk of conflict between the American statute and a foreign law . ..,12 Thus, instead of recognizing the broader set of regulatory interests and focusing analysis on the specific forms of conflict that application of U.S. law might create, the decision uses the theoretical possibility of conflict as an excuse for focusing on only the narrowest possible regulatory interest.

The virtue of using a comity-based approach, by contrast, is that it would focus attention on how our domestic interests coincide with, overlap with, and indeed sometimes conflict with the interests of other nations. It would therefore help our courts focus on the specifics of how particular modes of enforcement play out in the international arena. So, for instance, I agree that a transaction-based test makes sense in foreign-cubed class actions, not because Congress cares only about transactions taking place in our markets, but because such lawsuits create a variety of second-order substantive and procedural conflicts with other countries (such as conflicts over the acceptability of opt-out class actions) that are for the moment insurmountable. ${ }^{13}$ That specificity is important as we consider the approach of U.S. courts

\footnotetext{
${ }^{10}$ Elliott Assocs. v. Porsche Auto. Holding SE, 2010 WL 5463846 (S.D.N.Y. 2010).

"See Hannah L. Buxbaum, Transnational Regulatory Litigation, 46 VA. J. INT'L L. 251 (2006)

12 Morrison, 130 S.Ct. at 2877-78 (emphasis added).

${ }^{13}$ See Hannah L. Buxbaum, Multinational Class Actions Under Federal Securities Law: Managing Jurisdictional Conflict, 46 Colum. J. Transnat'l L. 14, 60-64 (2007).
} 
to cross-border cases, and the way in which their resolution of such cases intersects with other efforts at international economic regulation.

There is much debate about the appropriate course to chart in regulating global economic markets-and part of that debate turns on the role of private versus public enforcement. The Morrison opinion is troubling in that it encourages disengagement from that debate in the name of a falsely parochial national interest. 